\title{
ESO-1 Reactive Autologous Tumor Infiltrating Lymphocyte
}

National Cancer Institute

\section{Source}

National Cancer Institute. ESO-1 Reactive Autologous Tumor Infiltrating Lymphocyte. NCI Thesaurus. Code C38120.

Tumor infiltrating lymphocytes (TIL) isolated from a patient, exposed to the tumorassociated protein ESO-1 in vitro, and then transferred back to the same patient to target tumor cells expressing ESO-1. ESO-1 is a human self-antigen expressed by melanomas. The ESO-1 gene encodes several MHC class I- and MHC class II-restricted epitopes which may activate cytotoxic T-cell-mediated tumor destruction. (NCI04) 